\title{
Political Discourses of Trust: Stance-taking Acts in the Thai PM's Weekly TV Addresses
}

Melada Sudajit-apa*

Department of English and Linguistics, Thammasat University, Rangsit Campus, Khlong Luang, Pathumthani 12120, Thailand

Corresponding Author: Melada Sudajit-apa, E-mail: melada.s@arts.tu.ac.th

\section{ARTICLE INFO}

Article history

Received: September 11, 2019

Accepted: November 18, 2019

Published: December 31, 2019

Volume: 10 Issue: 6

Advance access: December, 2019

Conflicts of interest: None

Funding: None

Key words:

Stance-taking Acts

Trust-building

Political Discourse Analysis

Thai Politics

Critical Discourse Analysis

\begin{abstract}
This study aims to investigate the Thai PM Gen Prayuth Chan-o-cha's use of stance expressions to construe trust, comprising attitudinal stance, epistemic stance and modality, in his weekly addresses broadcast on national television from March to December, 2017. The linguistic investigation incorporating Critical Discourse Analysis and trust frameworks shows that the three main aspects of trust are pursued. Integrity is however predominantly constructed through the use of a modal verb k ${ }^{\text {h}}$ ’: 'would like' and an attitudinal verb jà:k 'want'. Interestingly, a relatively small number of stance markers are found to project competency and benevolence. The results have led to the conclusion that the PM's trust-building strategies mainly involve the construal of integrity by asserting his moral values linked with national reform, reconciliation, and advancement. These characteristics of linguistic hegemony via the construction of trustbuilding are expected to raise more sociopolitical awareness in the Thai political context.
\end{abstract}

\section{INTRODUCTION}

To retain power and stability, politicians have sought ways to build trust through taking action to establish a sustainable approach to national development. Politicians' trustworthiness, however, is mainly manifested by discourse, a form of social practice in which societal power relations are embedded, produced and reproduced through the use of language. Trustworthiness has been evaluated as constructed from three main aspects: competency, integrity, and benevolence (Fuoli \& Hart, 2018; Fuoli, 2016; Wang, 2016; Prevost, Brodeur, Onishi, Lepage \& Gold, 2015; Simpson, Harrell \& Willer, 2013). The person's competency is strongly linked with our impression that the person is able to deal with difficulties and take control of unexpected situations. It is also believed that we tend to mentally assess the person's integrity based on our sense that they are committed to moral beliefs and principles in addition to acting upon a promise. Finally, the trustworthy person tends to be one who has good intentions, as well as empathy towards others.

Recent research on the discursive construction of trust within the realm of Critical Discourse Analysis and Communication has incorporated the investigation of linguistic devices such as lexical choices, stance-taking expressions, metaphors, and discursive strategies in trust-building. For instance, Salvi, (2017)'s work focused analysis on how trust is discursively constructed in European political communication through the investigation of lexical choices linked with immigration issues. Fuoli (2017) examined the relationship between trustworthy corporate identity and the use of specific types of stance markers and constructions. Wang (2016), investigated how Chinese locals dealt with the 2015 Tianjin blasts. Wang found unsatisfactory crisis communication when officials merely focused on the construction of competency, whereas satisfactory officials constructed all three aspects of trust by providing information with credible evidence.

This present study focuses on a critical and linguistic analysis of the Thai PM Gen Prayuth Chan-o-cha's weekly addresses broadcast across Thai national television and radio stations from March 2017, when a 'reconciliation social contract' and the initial plans for a general election were approved, to December 2017. To shed light on how the PM's trustworthiness is discursively constructed, stance expressions comprising attitudinal stance, epistemic stance and modality (Conrad \& Biber, 2000) collocated with the personal pronoun $p^{h \text { ŏm }}$ 'I' were examined, relying on Critical Discourse Analysis's theoretical framework, to explore (1) what Thai stance markers were used by the Thai $\mathrm{PM}$ as the military leader to mediate his personal quality of trustworthiness; (2) how those particular stance markers 
were used across stance construction types; and (3) what plausible interpretations underlying the use of specific types of stance markers and constructions were in relation to the construction of trust. The linguistic investigation is the main focus of this study as it can be explained without overtly relying on personal interpretations (e.g. non-speech elements including facial expression, volume or gaze) (Carreon \& Svetanant, 2017).

Since contextualization of discourse data is very important, this section investigates the social processes in the period the speeches were delivered to achieve better understanding of the contexts (De Saint-Georges, 2013; Bloommaert \& Bulcaen, 2000). In 2014, General Prayuth Chan-o-cha launched a coup, dissolving the former Government. Since then, the Thai military government under him has claimed to attempt to heal political division and polarization between the movements which had fought against each other for more than a decade on the grounds of economic and social inequality. To achieve a peaceful and unified society, a 'reconciliation social contract' was approved in March 2017, with the primary focus on the Civil-State partnership model - inviting people, government and businesses to work closely together to pursue sustainable development, helping farmers, workers and communities secure their livelihoods. It aimed to strengthen the country's economy at the grassroots level, empowering local communities and enterprises towards development goals. Additionally, the national reconciliation process was regarded as part of the military government's plan to restore democracy, preparing for a general election of 2019, after which General Prayuth Chan-o-cha has returned as the PM.

Immediately after the successful coup, the TV program "Returning Happiness to the Nation's People" was broadcast weekly between May 2014 and October 2016 across all national television and radio stations, on Fridays from 8:15-8:45 pm. This program was initially produced to seek the understanding of the Thai people after the coup, helping ensure the stability of the military government. In October 2016, the TV program title was changed to "From the Sufficiency Economy Philosophy to Sustainable Development Goals" to honor and pay tribute to the legacy of His Majesty the late King Rama IX by highlighting the King's philosophy, along with promoting the PM's 12 national core values, primarily concerned with upholding the three 'pillars': Nation, Religions, and Monarchy.

\section{LITERATURE REVIEW}

\section{Political Discourse Analysis}

Political discourse is possibly the most widespread social domain topic that Critical Discourse Analysis practitioners have continuously worked on, attempting to find ways to raise people's awareness of manipulation, exploitation, power abuse, political ideology, and social inequalities (Chilton, 2004; Wodak, 2009; Fairclough \& Mauranen, 1997; van Dijk, 2007; Fairclough, 1992). This study adopted Fairclough $(2010,2003)$ 's three-dimensional framework for formulating and analyzing discourse by initially looking into linguistic features and organization of instances of discourse. Clearly, language and politics are intertwined in the way that wording and phrasing are related to political concepts and values. Chilton (2004) emphasizes that "political activity does not exist without the use of language" (p.6).

It is also noted that both the semantic and syntactic aspects of language play roles in shaping different conceptualizations of political ideology. For instance, when the agent is obscured and passive verb forms are used by politicians, this syntactic alternative can produce different impressions from when an active verb form is chosen (Machin \& Mayr, 2012). Bloommaert \& Bulcaen (2000) categorize the linguistic features and organization of instances of discourse into "choices and patterns in vocabulary, grammar, cohesion, and text structure" (p. 448). All these features of language need to be systematically analyzed in order to shed light on the relationship between the linguistic analysis and the social practices analyzed (Wodak, 2009).

Once a discourse-as-text dimension is accomplished, CDA practitioners attempt to link those linguistic features with the context by investigating how specific texts are produced, reproduced, distributed and consumed as well as incorporating macro conditions. The last CDA dimension proposed by Fairclough is discourse-as-social practice, which aims to draw on the ideological effects and hegemonic processes in which a particular discourse is constituted, and, if possible, raise social awareness and resist hegemony (Fairclough \& Mauranen, 1997).

\section{Trust-building and Stance-taking Acts}

Stance expressions comprise several linguistic devices to express speaker's attitudes, personal feelings, assessments, or moral judgments (Conrade \& Biber, 2005; Biber, Conrad, $\&$ Cortes, 2004, Biber et al, 1999). Stance markers linked with the enactment of trust can be divided into three main semantic/functional classifications: (1) epistemic stance (2) attitudinal stance, and (3) modality (Fuoli \& Hart, 2018). Epistemic stance markers express the knowledge status of information in a following proposition: certainty, uncertainty, or likelihood, which can be manifested in the following construction types: (1) certainty verb + post-predicate complement clause (e.g. anticipate, ascertain, conclude, confirm, establish, find, know, perceive, realize, show, understand, verify, etc.), (2) likelihood verb + post-predicate complement clause (e.g. appear, assume, believe, consider, doubt, expect, feel, gather, guess, imagine, indicate, infer, sense, suggest, suppose, suspect, think, etc.), and (3) likelihood noun + that-complement clause (e.g. assumption, belief, claim, doubt, estimate, etc.) (see Fuoli, 2017).

Attitudinal stance markers are used to signal the speaker's attitudes towards actions, events, values, and concepts manifested in the following construction types: (1) desire/ intention/decision verb + to-complement clause (e.g. aim, commit, crave, dedicate, intend, look, mean, necessitate, need, plan, require, seek, strive, want, wish, would like, etc.), (2) emotion/attitude adjective + post-predicate complement clause (e.g. afraid, concerned, delighted, interested, pleased, sad, thankful, worried, etc.), and (3) evaluation 
adjective + post-predicate complement clause (e.g. annoying, critical, embarrassing, important, necessary reasonable, etc.) (see Fuoli, 2017). The final category of stance expressions are in the form of modality, expressing (1) permission/possibility/ability (e.g. can, could, may, might, etc.), (2) necessity/ obligation (e.g. must, should, etc.), and (3) volition/prediction (e.g. shall, will, would, etc.) (see Fuoli, 2017).

In Thai grammar, Thai stance markers exist in a similar categorization as classified by Fuoli (2017), though with more variations in terms of construction types and semantic functions of epistemic verbs. Kitikanan (2012) found 10 types of Thai verb complementation. Prasithrathsint (2009) further explained that the occurrence of each of the complementizers depends on the type of verb in the matrix clause. For instance, the complementizer thîi occurs with emotive verbs, whereas wâ: is found with communicative verbs. Similarly, hây occurs with directive verbs. Some epistemic verbs like tว:y.ka:n 'want' can function as a manipulative verb if followed by hây as well as functioning as a modal verb when the subject in the main clause also serves to function as the subject of verb complement. Rangkupan (2005) investigated a system of epistemic modality in Thai and established four syntactic categories: (1) preverbal auxiliaries, (2) initial particles, (3) adverbs, and (4) final particles. Epistemic modality can also be classified into five semantic categories: (1) assumptive, (2) speculative, (3) deductive, (4) dubitative, and (5) certainty.

\section{METHODOLOGY}

This present study examined the Thai PM's use of specific stance-act markers in manifesting his personal quality of trustworthiness by analyzing a total of 44 weekly addresses in the TV program From the Sufficiency Economy Philosophy to Sustainable Development Goals, from March 3, 2017 to December 29, 2017, aired on national television and radio stations on Fridays between $8: 15$ and 8:45 pm. The addresses were retrieved from the website of the Royal Thai Government at http://www.thaigov.go.th both as YouTube video clips and verbatim transcriptions. The total number of words in the 44 weekly addresses is 554,896 and the total number of the personal pronoun $p^{h}$ orm ' $\mathrm{I}$ ' is 1,329 . Table 1 summarizes the details of each TV address.

At the micro level, the procedure to identify and quantify first personal pronoun use was achieved with MSWord's advanced find function prior to proceeding with careful manual word and utterance semantic/functional analysis, taking into account the context from which the data were drawn. As discussed previously, stance markers which could not be identified as belonging to the PM's personal identity, like 'government', were excluded. The present study aims to analyze stance markers collocating with the personal pronoun $p^{h}$ orm 'I' only. The framework for analyzing stance-taking acts proposed by Fuoli (2017) and for analyzing Thai verb complements and modality in the system of Thai grammar by Kitikanan (2012) were incorporated into the manual

Table 1. Summary of information of the weekly addresses

\begin{tabular}{|c|c|c|c|c|c|}
\hline Tv weekly addresses & Words & I & Tv weekly address & Words & I \\
\hline March 3, 2017 & 11,305 & 39 & August 4, 2017 & 15,149 & 20 \\
\hline March 10, 2017 & 10,344 & 27 & August 11, 2017 & 14,022 & 25 \\
\hline March 17, 2017 & 15,793 & 50 & August 18, 2017 & 9,893 & 24 \\
\hline March 24, 2017 & 18,913 & 32 & August 25, 2017 & 9,202 & 21 \\
\hline March 31, 2017 & 11,731 & 25 & September 1, 2017 & 11,457 & 21 \\
\hline April 7, 2017 & 12,173 & 21 & September 8, 2017 & 11,092 & 25 \\
\hline April 14, 2017 & 11,737 & 24 & September 15, 2017 & 11,920 & 29 \\
\hline April 21, 2017 & 12,871 & 33 & September 22, 2017 & 15,829 & 42 \\
\hline April 28, 2017 & 11,183 & 19 & September 29, 2017 & 9,945 & 38 \\
\hline May 5, 2017 & 11,754 & 26 & October 6, 2017 & 5,908 & 24 \\
\hline May 12,2017 & 15,427 & 40 & October 13, 2017 & 5,371 & 4 \\
\hline May 19, 2017 & 13,667 & 30 & October 20, 2017 & 14,263 & 21 \\
\hline May 26, 2017 & 18,643 & 47 & October 27, 2017 & 3,212 & 5 \\
\hline June 2, 2017 & 13,517 & 25 & November 3, 2017 & 13,480 & 28 \\
\hline June 9, 2017 & 9,823 & 14 & November 10, 2017 & 7,897 & 26 \\
\hline June 16, 2017 & 20,615 & 82 & November 17, 2017 & 13,141 & 36 \\
\hline June 23, 2017 & 16,574 & 25 & November 24, 2017 & 11,189 & 18 \\
\hline June 30, 2017 & 10,960 & 17 & December 1, 2017 & 18,590 & 118 \\
\hline July 7, 2017 & 16,052 & 28 & December 8, 2017 & 8,641 & 10 \\
\hline July 14, 2017 & 12,893 & 21 & December 15, 2017 & 9,003 & 16 \\
\hline July 21, 2017 & 17,116 & 43 & December 22, 2017 & 16,288 & 46 \\
\hline July 28, 2017 & 13,211 & 23 & December 29, 2017 & 13,102 & 41 \\
\hline Total & Words $=554,896$ & $\mathrm{I}=1,329$ & & & \\
\hline
\end{tabular}


analysis by identifying lexical choices that can be categorized as stance markers (epistemic stance, attitudinal stance, and modality) and then categorizing each identified stance marker collocating with the personal pronoun $p^{h}$ om 'I' into the sub-categories of trust components: benevolence, competency, and integrity.

As the present study relied on Fairclough $(1992,2003)$ 's Critical Discourse Analysis framework, the macro-level analysis of discourse was carried out after the linguistic investigation to explore the conditions of production of the identified stance markers. More specifically, it intended to explain why particular types of stance markers were employed by the PM and why certain aspect of trust were paid more particular attention than others, with the hope to raise sociopolitical awareness of linguistic hegemony via the construction of trust-building.

\section{RESULTS AND DISCUSSION}

\section{Overall Distribution of Stance Markers}

This section focuses on the analysis of the stance markers used by the Thai PM in his weekly addresses to enact his identity as a trustworthy politician. The overall distribution of Thai stance markers projecting the three main aspects of trust-building strategies - benevolence, integrity, and competency - is illustrated in Table 2. The specific construction types of stance markers categorized into 'benevolence', 'integrity', and 'competency' is then discussed.

Table 2 illustrates that the majority of stance markers used represent the PM's personal stance in terms of trust-building categorized as language used to enact integrity, whereas around 23 and 6 percent of all the stance markers found in the data were linguistic devices projecting competency and benevolence, respectively. The examples of stance markers used to signal integrity are $k^{h}$ כ̌ 'would like', jà: $k$ 'want', hěn 'think' which were found to express the PM's moral beliefs. The remaining stance markers are those connected with the construal of competency (e.g. dâj 'be able to', cà? 'will') and benevolence (e.g. hěn 'see', $k^{h} \hat{a} w c a j$ 'understand'), which were found to express the PM's ability to deal with specific issues, and inter-subjectivity or the interchange of thoughts and feelings between the speaker and audience, respectively. The detailed analysis underlying the use of stance markers is given in the next sections.

\section{Stance Markers and Constructions Projecting Benevolence}

Based on the findings in Table 2, the PM's weekly addresses were scarcely concerned to emphasize inter-subjectively

Table 2. Overall frequency of stance markers constructed from the three components of trust

\begin{tabular}{lcc}
\hline Components & Frequency of stance markers & Percentage \\
\hline Benevolence & 54 & $6.05 \%$ \\
Integrity & 633 & $70.97 \%$ \\
Competency & 205 & $22.98 \%$ \\
Total & 892 & $100 \%$ \\
\hline
\end{tabular}

shared thoughts and feelings with the people, as only 6 percent of the stance markers used by the PM were found to project benevolence. Table 3 reports the specific types of stance markers as well as the frequency and distribution of those stance markers and constructions concerning benevolence.

Table 2 illustrates that the majority of stance markers used represent the PM's personal stance in terms of trust-building categorized as language used to enact integrity, whereas around 23 and 6 percent of all the stance markers found in the data were linguistic devices projecting competency and benevolence, respectively. The examples of stance markers used to signal integrity are $k^{h}$ \%: "would like', jà:k 'want', hěn 'think' which were found to express the PM's moral beliefs. The remaining stance markers are those connected with the construal of competency (e.g. dâj 'be able to', cà? 'will') and benevolence (e.g. hèn 'see', $k^{h} \hat{a} w c a j$ 'understand'), which were found to express the PM's ability to deal with specific issues, and inter-subjectivity or the interchange of thoughts and feelings between the speaker and audience, respectively. The detailed analysis underlying the use of stance markers is given in the next sections.

\section{Stance Markers and Constructions Projecting Benevolence}

Based on the findings in Table 2, the PM's weekly addresses were scarcely concerned to emphasize inter-subjectively shared thoughts and feelings with the people, as only 6 percent of the stance markers used by the PM were found to project benevolence. Table 3 reports the specific types of stance markers as well as the frequency and distribution of those stance markers and constructions concerning benevolence.

As Table 3 shows, the Thai verbs hěn 'see', $k^{h a ̂ w c a j}$ 'understand', and mâj rú:/ mâj sa:p 'don't know' are the three most frequent epistemic verbs, against the remaining epistemic verbs found to enact benevolence in the weekly addresses. The Thai verb hěn 'see' is used as a grammatical marker of epistemic stance in a certainty verb + nominalized complement construction as shown in the following examples.

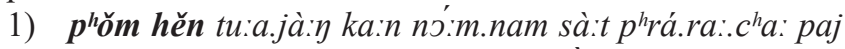
prà.júk $c^{h a ́ j}$ con prà.sòp.phǒn.săm.rèt

PN: 1SG Verb:to see example conveyance the king's philosophy DIR to apply until to succeed

(I have seen examples of embracing the King's Philosophy and adopting it successfully.) (November 24, 2017)

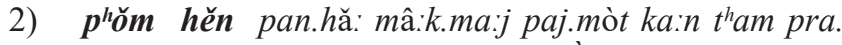
$c^{h} a: p^{h} i$ ca:n tồy sâ:y ka:n ráp.rú: kj̀n

PN: 1SG Verb:to see problem many absolutely/whatsoever

(I have seen too many problems. We must build people's awareness before conducting the public hearing.) (December 1, 2017)

Utterances of the PM's good intentions with the verb hèn 'see' are used to highlight the PM's shared knowledge or cognizance of Thailand's situation, proving that he is a leader 
Table 3. Overall frequency of stance markers and construction types involving 'benevolence'

\begin{tabular}{|c|c|c|c|}
\hline Markers & Frequency & Percentage & Stance Type/Construction type \\
\hline hěn 'see' & 14 & $25.93 \%$ & $\begin{array}{l}\text { Epistemic stance } \\
\text { certainty verb + nominalized complement }\end{array}$ \\
\hline$k^{h a ̂ w c a j ~ ' u n d e r s t a n d ' ~}$ & 12 & $22.22 \%$ & $\begin{array}{l}\text { Epistemic stance } \\
\text { certainty verb }+ \text { sentential complement following wâ:/ nominalized } \\
\text { complement/ no verbal complement }\end{array}$ \\
\hline mâj rú:/ mâj sa:p 'don't know' & 10 & $18.52 \%$ & $\begin{array}{l}\text { Epistemic stance } \\
\text { certainty verb }+ \text { sentential complement following } w \hat{a}: /\end{array}$ \\
\hline sa:p / rú: 'know' & 5 & $9.26 \%$ & $\begin{array}{l}\text { Epistemic stance } \\
\text { certainty verb }+ \text { sentential complement following } w \hat{a}: /\end{array}$ \\
\hline rápfây 'consider' & 4 & $7.41 \%$ & $\begin{array}{l}\text { Epistemic stance } \\
\text { likelihood verb }+ \text { nominalized complement }\end{array}$ \\
\hline mâj hěn 'don't find' & 3 & $5.56 \%$ & $\begin{array}{l}\text { Epistemic stance } \\
\text { certainty verb + verb-phrasal complement/ sentential complement }\end{array}$ \\
\hline sa:mphât 'feel' & 2 & $3.70 \%$ & $\begin{array}{l}\text { Epistemic stance } \\
\text { likelihood verb + nominalized complement following } d \hat{a} j t^{h} \hat{u} \eta\end{array}$ \\
\hline ráprú: 'perceive' & 2 & $3.70 \%$ & $\begin{array}{l}\text { Epistemic stance } \\
\text { certainty verb + nominalized complement following/not following } \\
\text { dâj th } t^{h} \eta\end{array}$ \\
\hline mâj $k^{h a ̂ w c a j ~ ' d o n ' t ~ u n d e r s t a n d ' ~}$ & 1 & $1.85 \%$ & $\begin{array}{l}\text { Epistemic stance } \\
\text { certainty verb (intransitive verb where no complementation occurs) }\end{array}$ \\
\hline hěncaj 'empathize' & 1 & $1.85 \%$ & $\begin{array}{l}\text { Epistemic stance } \\
\text { certainty verb (intransitive verb where no complementation occurs }\end{array}$ \\
\hline Total & 54 & $100 \%$ & Epistemic stance \\
\hline
\end{tabular}

who is attentive to the Thai people's well-being. In 2), the PM claims insightful understanding of multifaceted issues. Since he understands the phenomenon well, he also knows how to cope with them. Apart from claiming full awareness of the country's problems, the PM also acknowledges positive developments claimed to result from his actions and support, as shown in 1). The manifestation of shared understanding creates the impression of 'being there' for the Thai people. This is used to emphasize his identity as a benevolent and altruistic leader.

In addition to the use of the verb hen 'see', another epistemic verb that was frequently found is $k^{h} \hat{a} w c a j$ 'understand', which serves to project benevolence by empathizing with people's problems and showing that he is devoted to assist with solutions. The epistemic verb $k^{h} \hat{a} w c a j$ 'understand' is used as a grammatical marker of epistemic stance in the following constructions: (1) a certainty verb + sentential complement following wâ:; (2) a certainty verb + nominalized complement; (3) and a certainty verb without verbal complements as shown in the following instances.

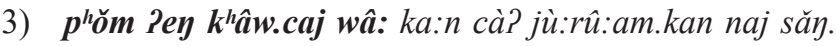
$k^{h}$ om dâj jà:y.pen.pà.ka.tì?.sùk nán raw tôy ?a:săj táy kòt.ma:ǰ.ca:.rî:t.prà.phe.ni: lé? kòt.ma:j̆.la:j.lák.Pak.sǒ:n

PN:1SG myself Verb:to understand COMP NMZ ASP to live together insociety MOD: POSSI ABI happily and safely EMP PN: 1PL INCL MOD: OBL to abide both common law and civil law

(I myself understand that to live together in the society happily and safely, we must rely on the common law and civil law.) (April, 21, 2017)
4) $\boldsymbol{p}^{h \boldsymbol{o}} \boldsymbol{m} \boldsymbol{k}^{h} \hat{\boldsymbol{a}} \boldsymbol{w} . \mathbf{c a j} k^{h} w a: m . d \grave{u}:$ at.rón $k^{h} \zeta \check{y} t^{h} \hat{a} n$ PN:1SG Verb:to understand trouble POSS you tè thân tôy $k^{h} \hat{a} w . c a j k^{h} w a: m . d \grave{u}: a t . r o ́ n ~ k^{h}$ y̆y prà.thêt diu:aj (I understand your hardship, but you must understand the country's hardship too.) (July, 7, 2017)

5) lă:j k $k^{h}$ on kjî̀ Pàit cà jay lam.bà:k.caj jù:

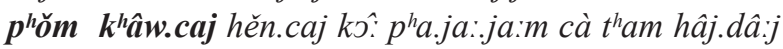

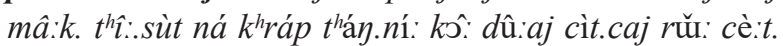

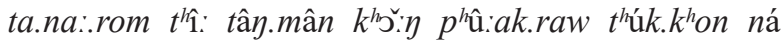
$k^{h}$ ráp

\section{PN:1SG Verb:to understand}

(Many people may still feel uncomfortable. I understand, empathize and will try to help as much as I can with our heart and strong will.) (September 1, 2017)

From the findings above, the PM claims an in-depth understanding of Thailand's problems in logic by indicating causes of problems when the verb $k^{h} \hat{a} w c a j$ 'understand' is used in a certainty verb + sentential complement following wâ: as shown in 3). To illustrate this, in 3), the PM logically ascribes both common law and statue law to our peace in the society. The verb $k^{h} \hat{a} w c a j$ 'understand' is further used to display empathy towards people's difficulty, but with the use of a nominalized complement, conceals actual causes of hardship, as shown in 4). The disclaimers ideological discourse strategy 'I understand it, but...' structure (van Dijk, 2013) is used with the verb $k^{h} \hat{a w c a j}$ when it is followed by nominalized complements to express apparent empathy while at the same time negatively representing others (people who oppose him). Doing so, he represents himself as a devoted politician attempting to resolve conflicts and social issues while other people oppose him. Finally, when the verb $k^{h} \hat{a} w$ - 
caj functions as an intransitive verb with no verb complements as in 5), it is used to emphasize the PM's sympathy and his devotion to help people and the nation to the fullest.

The other frequently used type of epistemic stance expressions that convey the construction of benevolence is mâj rú:/mâj sa:p 'don't know'. This grammatical marker is commonly used in a certainty verb + sentential complement following wâ:: Here are some instances conveying mâj rú:/ mâj sa:p.

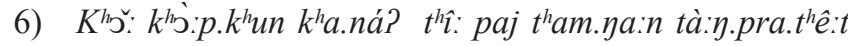

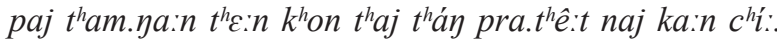
ce:y tè: mi: $k^{h}$ on ba:y $k^{h}$ on ba:y pra.phê.t ?aw paj pra. ca:n

$p^{h}$ ǒm mâj rú: wâ: $k^{h}$ on làw.nân pen $k^{h}$ on thaj rŭ: mâj PN:1SG NEG Verb:to know COMP people those to be people Thai or not

(I would like to thank the team for working on behalf of Thai people in explaining what has happened overseas. However, there are some types of people who try to vilify. I don't know whether those people are Thai or not.) (March 17, 2017)

The epistemic stance expression mâj rú:/mâj sa:p 'don't know' shown above was found to serve as a disclaimer ideological discourse strategy (van Dijk, 2013) that the PM used to represent himself positively and negatively represent other social actors. In so doing, he emphasized his devotion, responsibility, and commitment to the nation and to negatively represent others who appear to criticize and oppose him as 'apparently not Thai people' as shown in 6). Thus, the use of this stance expression is not linked with a genuine lack of knowledge and research but rather involves negative representation of others, emphasizing his positive side.

\section{Stance Markers and Constructions Projecting Integrity}

Analysis of stance expressions enacting construal of integrity shows that the most frequently used stance markers in the weekly addresses are 'attitudinal stance' markers and 'epistemic stance' expressions. The former concern expressions of personal attitudes, emotions, feelings, value judgments and moral beliefs, whereas the latter stance acts involve 'believing' and 'thinking' used to signal the speaker's moral values and principles. Attitudinal stance can be used as an indicator revealing degrees of integrity, provoking people's judgment of the PM's trustworthiness. Table 4 shows the overall frequency stance markers and constructions concerning integrity.

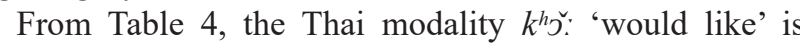
used the most frequently, representing $27.39 \%$ of all stance expressions involving integrity. To be precise, this grammatical marker of attitudinal stance is found in the following constructions: (1) a volition modality + verb-phrasal complement construction; (2) an attitudinal verb used in a desire/intention/decision verb + verb-phrasal complement following hâj construction; and (3) an attitudinal verb used on a desire/intention/decision verb + sentential complement following $h a j j$. In the $2^{\text {nd }}$ and $3^{\text {rd }}$ constructions, $k^{h} y^{r}$ is found to function as a manipulative verb with the PM functioning as the manipulating agent. The manipulee, which belongs to the attitudinal verb $k^{h}$, is sometimes omitted but can still be inferred from the context (Givón, 1990). Here is an example of this grammatical marker of attitudinal stance projecting integrity.

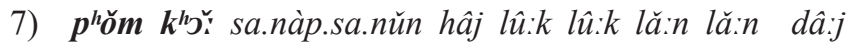
$t^{h} a m$ naj sìy thî: tây.caj wáj kàp $k^{h} u n . m \hat{\varepsilon}$ :

PN: 1SG MOD:VOL to encourage MAN the young/ young people MOD: POSSI ABI to dointhing RELto intend ASP: PERFBEN mother

(I would like to support all our children to keep their promises made to their mother.) (August 11, 2017)

In the system of Thai grammar, $k^{h} y^{2}$ ' 'would like' functions as a volition modal used to express personal desire and intention. From the analysis, $k^{h}$ r: is found to be most commonly used by the PM, to display a confident stance asserting moral beliefs he finds necessary for national reform that he would like Thai people to adopt. As we can see in 7), the PM expressed his personal morality by giving priority to showing gratitude and doing good deeds to mothers. He asserted that gratitude towards parents is a key to national development.

The other two constructions in which $k^{h} 5:$ is used are an attitudinal verb + sentential complement following hâj, as shown in 8) below. When $k^{h} y^{\longleftarrow}$ is used in this construction, the PM did not only require changed behaviour, but also asserted his personal stance linked with beliefs and values towards good citizenship. In 8) the quality of being patient and of adjusting mindsets are required by the PM, who ascribed them to success in conflict resolution.

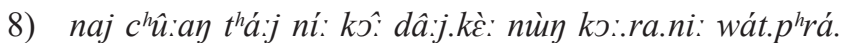
$t^{\text {ham.ma.ka:j }}$

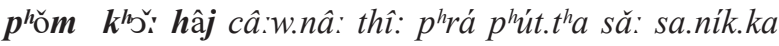

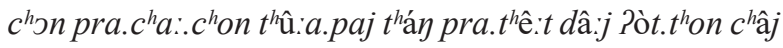
sa.tì.pan.ja: lé? wí.ca:.ra.ná.ja:n naj ka:n kề..khăj pan. hă: rû:am kan dîu:aj

PN:1SG MOD:VOL MAN government officer Buddhist monk Buddhist people (in) general whole country MOD: POSSI ABI to be patient

(This last part includes 1) The Dhammakaya Temple Case. I would like to ask for cooperation from the temple staff, the monks, Buddhists, and people all over the country to be patient, to use your intelligence and discretion to solve the problems altogether.) (March 3, 2017)

The second commonly used type of attitudinal stance marker concerning integrity is jà: $k$ 'want', which is used in the following constructions: (1) a desire/intention/decision verb (manipulative verb) + verb-phrasal complement following $h \hat{j} j$; (2) a desire/intention/decision verb (manipulative verb) + sentential complement following hâj; (3) volition modality + verb-phrasal complement; and (4) volition modality + verb-phrasal complement following cà?. The analysis of the PM's use of jà: $k$ 'want', when used as a volition modal, shows that $j a ̀$ : $k$ functions as the PM's expression of positive desire for Thailand's future. A promising sign of change in terms of human development is often stated, as in 9). Additionally, jà: $k$ is used positively to represent the PM by emphasizing that he is committed to improving peo- 
Table 4. Overall frequency of stance markers and construction types projecting integrity

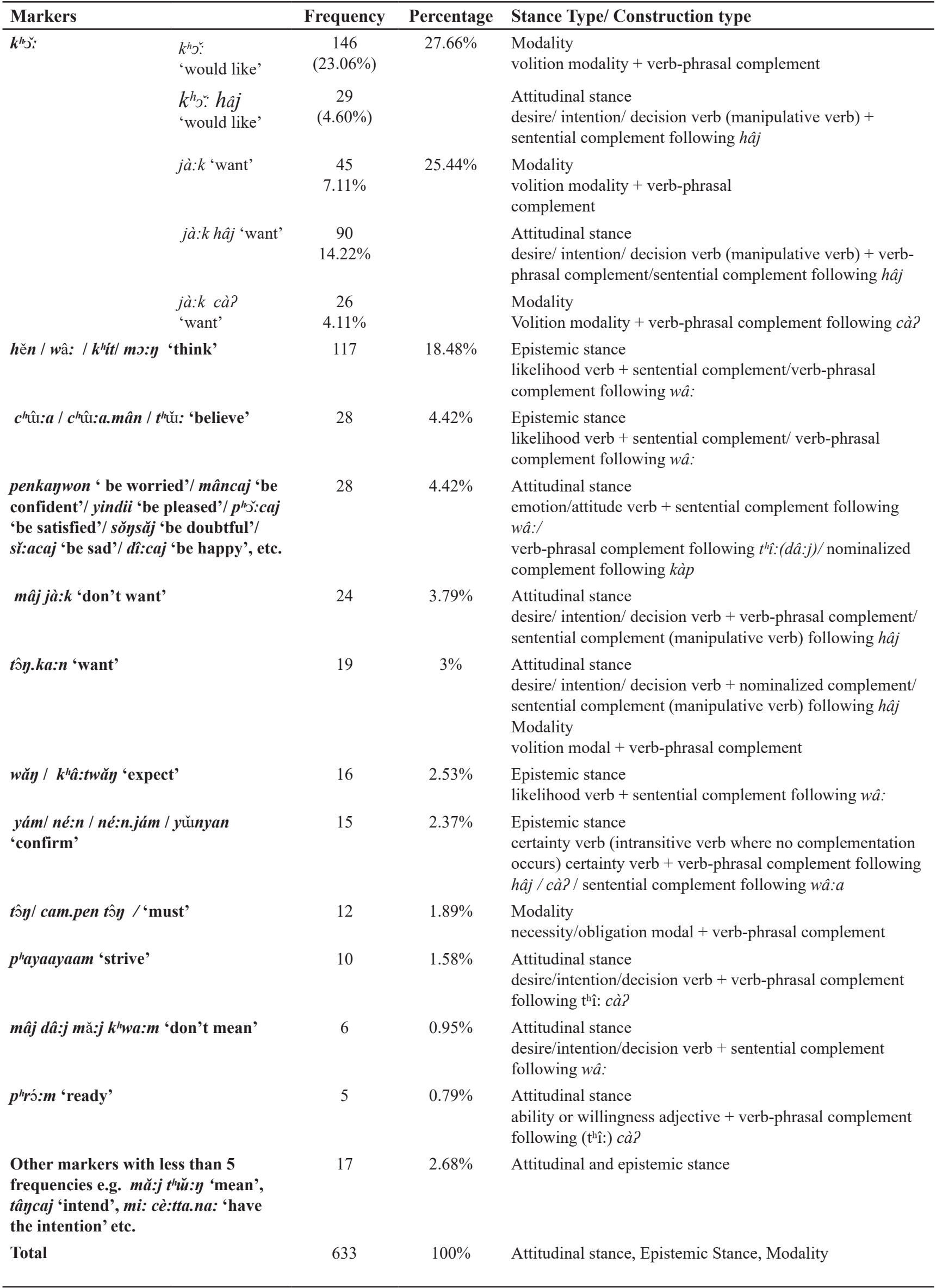


ple's quality of life sustainably, not in the short run, as in 10). In so doing, the PM asserts personal values, beliefs, and preferences in leadership, change, creativity, responsibility, sustainability, and technology development as these lay solid foundations for Thailand.

9) phǒm ?e:y jà:k hěn phî::nó:y.khâarâat.cha.ka:n

PN:1SG myself MOD:VOL Verb: to see government officer (in family sense)

$t^{h} a m . n a \hat{:}: t^{h} \hat{\imath i}$. pen $p^{h} \hat{u}:$.nam hèy ka:n.plian.ple:y to function as leader ofchange

(I myself would like to see that our government officers carry out their duties as the leaders for change.) (March 31, 2017)

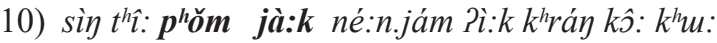

thing REL PN:1SG MOD:VOL Verb: to confirm again also COP

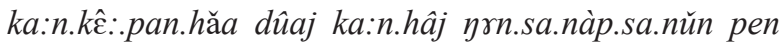

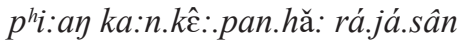

to solve problems by to give financial support

(What I would like to emphasize again is that solving problems with money is short-term.) (May 19, 2017)

Likewise, jà: $k$ used in a volition modal + verb-phrasal complement following cà? construction is used to teach Thai people about morality and good citizenship. However, the use of cà? 'will' as a volition/prediction modal verb emphasizes the higher degree of the PM's commitment and devotion to resolve the nation's problems and conflicts. This can be clearly seen in 11), when the PM strongly begged Thai citizens to consider and revise their own roles and duties as well as trying to have true understanding of the King's philosophy.

11) sùt.tháaj.ní: phŏm jà:k cà fà:k hâj

finally PN:1SG MOD:VOL TAM:PRSP IRR VOL to entrust MAN

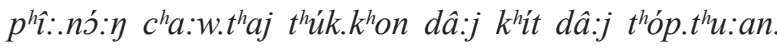
tu:a.?e:y

Thai people (in family sense) everyone MOD: EPIS think MOD: EPIS to review oneself

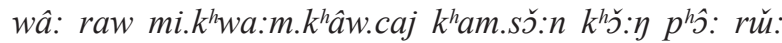
sà:t COMP

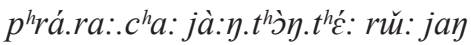

(Lastly, I would like to ask all of us Thais to think and ponder over ourselves to see if we clearly understand the teachings of our Father or the King's Philosophy.) (April 28, 2017)

The last type of $j a \grave{k} k$ concerning integrity is used in an attitudinal verb + sentential complement and verb-phrasal complement following hâj. It serves as a manipulative verb requiring a manipulee to collaborate with the government and others in society devoted to the nation. Again here, the concept of 'collaboration' and 'not only the government's responsibilities' is greatly emphasized and valued. As we can see in 12) and 13), the PM expresses his desire to see every party of society collaborate in order to drive national reform. He also wants everyone to build trust by doing good deeds and not wishing to gain one-way benefits, as in 13).

12) naj.p ${ }^{h} \hat{a}: p . r u: a m p^{h}$ ŏm jà:k hâj thúk. fà:j rû:am.mu: kan sâ:y

PN:1SG MOD:VOL MAN every part to cooperateto build up $k^{h}$ wa:m.châu:a.mân $k^{h}$ wa:m.wáj.wa:y.caj sûy.kan.lé?. kan $c^{h} \hat{u}: a j \quad$ kan $t^{h} a m$

trust/confidence

naj sì di: di: hâj kàp $k^{h}$ on thaj dî:aj.kan ?e:y

(Overall, I would like all parties concerned to cooperate to build confidence and trust in one another to perform good deeds for all of us.) (October 20, 2017)

13) phŏm jà:k hâj wáj.caj rát.tha.ba:n ní:

PN:1SG MOD:VOL MAN to trust government this

raw cà? $k^{h} \hat{u}: a p . k^{h} u m . d u: . l \varepsilon: t^{h} a m . h a ̂ j ~ k^{h} \hat{\jmath}: . k a \eta$.won.caj

tà:y tà:y làw.ní: dâ:j dam.nr:n.ka:n dâ:j

(I would like you to trust this government. We will ensure that these concerns will be addressed.) (June 23, 2017)

To project integrity, the study has found a substantial proportion of instances of the verb 'think' -hěn/ wâ:/ $k^{h}$ it/ $m s: y$ - in the addresses used to express attitudes that are strongly linked with moral beliefs and optimism about the countries future. This Thai likelihood verb in the epistemic stance is used in a likelihood verb + sentential complement and verb-phrasal complement following wâ: When these cognition verbs are followed by a verb-phrasal complement, subject in the verb-phrasal complement is omitted but can still be well-understood in context. Instances conveying this type of epistemic stance act are shown in 14) and 15):

14) phŏm hěn wâ: sìy $t^{h} \hat{\imath}:$ mi: sù:an săm. $k^{h} a n$

PN:1SG Verb:to think COMP thing REL to have part important

jà:y.mâ:k naj ka:n.pa.tì.rû:p mi: sǒ:y prà.ka:n khu:

very/highly in reformationto have two thing COP

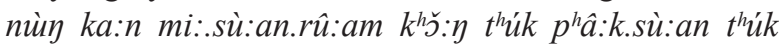

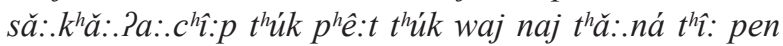
câ:w.k $k^{h}$ :y prà.thê:t pen $p^{h} \hat{u}: t^{h} \hat{\imath}:$ mi: sù:an.dâj.sù:an.š̀:a $t^{h} a ́ y . m o ̀ t$

(I noticed that there have been two important factors contributing to the reform: 1) the participation of all sectors, professions, people of all ages and genders as the owners of the country and the stakeholders.) (August 4, 2017)

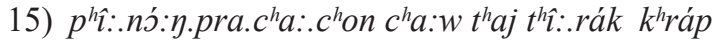
ka:n.phát.tha.na: châ:t.bâ:n.mu:ay jà:y jây.ju:n nán

phŏm hěn wâ: raw tôy pa.tì.rû:p ton.?e:y dî:aj

PN:1SG Verb:to think COMP PN: 1PL INCL MOD:

OBL to reform oneself by

ka:n.phát.tha.na: cit.caj să:m rá.dàp

development mindthree level

dâ.j.kè: nùy cit.săm.núk chên ka:n mi: khun.na.t ${ }^{h} a m$ ca.rí.ja.tham

(My dear Thai fellows,

For the sustainable development of our country, I think that we need to reform ourselves by improving our mind which includes 1) conscience such as virtue, ethics.) (December 8, 2017)

\section{Stance mMarkers and Constructions Projecting Competency}

The final component that we can focus on when analyzing the construal of trust through linguistic devices is 'competency' which has a strong connection with the use of permission/ability/ possibility modal verbs such as dâ:j 'be able to' and cà? 'will' 
to signal capabilities to achieve goals and deal with problems. They are also used to display determination to carry out certain actions and ensure that plans and goals can be accomplished. Although relatively low in terms of frequency, the obligation modal verb $t \hat{y} \eta$ 'must' and the epistemic verb $c^{h} \hat{u}: a / c^{h} \hat{u}: a . m a ̂ n$ 'believe' are also used to signal competency when expressing possibilities of plans being achieved in future. Table 5 shows the overall frequency of stance markers and constructions involving the discursive construction of competency.

In Table 5, possibility/ability modal verbs are by far the most common type of stance markers employed to highlight ability and possibility to accomplish certain actions and plans. The Thai modal dâ:j 'be able to' is found to be employed the most frequently with the speaker's emphasis on past actions he was able to manage or achieve. Semantically, this modal also signals the meaning of 'having an opportunity/possibility to do or accomplish something'. Thus, the sense of trust is likely to be discursively transmitted through the use of this modal verb. The Thai modal verb dâ:j 'be able to' is used as a grammatical marker in the following construction: a possibility/ ability modal + verb-phrasal complement. Below are examples of instances in which dâ:j was used:

16) phŏm dâ:j sày.ka:nq hâj thúk nù:aj.ya:n

PN:1SG MOD:POSSI ABI to enjoin MAN every department

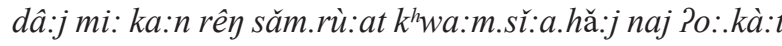

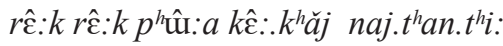

(I have ordered all agencies to take immediate action on the surveys to find damages in the first round.) (August 4, 2017)

17) phŏm dâ:j hă:ru: kàp nù:aj.ya:n tà:y.tà:y PN:1SG MOD:POSSI ABI discuss COM department various

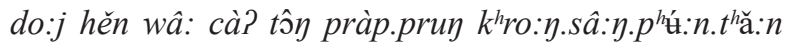

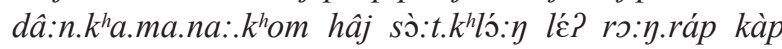
ka:n t̀̀:p.to: $t^{h} a: \eta$.sè:t.t $t^{h} a . k i t$

(I had a chance to consult with different agencies and have concluded that we need to improve the transport infrastructure in response to economic growth.) (August 25, 2017)

The other commonly used modal of volition/prediction to be discussed here is cà? ' will', which is found to be in a volition/ prediction modal + verb-phrasal complement. The analysis suggests that the PM attempted to emphasize his goals and objectives to solve conflicts and social issues. The Thai modal verb $c \grave{a}$ ? is also used to underline PM's strong will to accomplish those goals and to presuppose that he is likely to be committed to carry out the goals he established. It is noted that concrete material processes, such as 'do', 'follow', or 'proceed', following the modal verb cà?, as shown in 18) and 19) is value added to the PM's competency as those lexical choices connote 'concrete actions' (Machin \& Mayr, 2012). The instances conveying the use of this modal verb are illustrated below.

18) naj.Pa.na:.. $k^{h}$ ót t̀̀.paj

phŏm cà? dam.nə:n.ka:n jà:y.tò:nû:ay

PN: 1SG TAM:PRSP IRR VOL proceed continuously

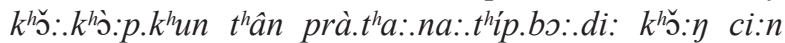
$d \hat{u}: a j$

(In the future I will proceed continuously. I would also like to thank President of the People's Republic of China.) (September 8, 2017)

19) sìn năj tham dâ:j phŏm cà? tham

thingwhichever to do MOD: POSSI ABI PN:1SG TAM:PRSP IRR VOL do

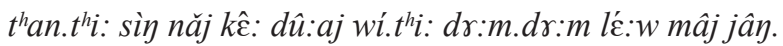
$j u: n$ immediately

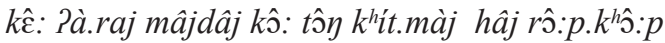

(I will do immediately whatever is possible. Any issues that cannot be solved in the long term need to be carefully considered.) (August 11, 2017)

The results of stance-act analysis demonstrate that the PM discursively constructed all three aspects of trust via his weekly addresses, a form of media hegemony revealing his values, norms, ideology, and manipulation from March-December 2017. Of the three aspects of trust, integrity was found to be most commonly construed (71\%) through the use of the Thai volition modal verb $k^{h} \breve{\text { : }}$ and attitudinal verb jà: $k$ hâj, as shown in Table 3. The frequency of the use of these two stance markers was far more substantial than any other type of stance marker used. Semantic interpretation revealed that the Thai modal verb $k^{h}$ : : appears to serve the PM's assertive stance in transmitting his attitudes, values and moral beliefs which he ascribed to the nation's reform, reconciliation, and advancement. He displays his integrity by requiring the Thai people to strictly practice the Buddhist precepts, to show gratitude to parents and seniors, to embrace the King's philosophy, and to collaborate with each other in society. All these are means to create peace and order and manipulate the people to ensure that conflicts are resolved. Likewise, the desire/intention/decision or attitudinal verb jà: $k$ which is used in an attitudinal verb + verb-phrasal complement following hâj is used to project his integrity revealing his need to change the Thai people and the entire nation by requiring them to conform with what he finds morally right, such as the 12 national core values. We can find substantial instances demonstrating his desire to witness Thai people's devotion to the nation and collaboration with the government.

The aspects of competency and benevolence were far less pursued. The results show only $23 \%$ and $6 \%$ of stance markers used to manifest these two, respectively. The two most commonly used modal verbs dâ:j 'be able to' (possibility/ ability modal verbs) and $c \grave{a}$ ? 'will' (volition/prediction modal verbs) were found to express competency in having opportunities to accomplish political plans to reform the nation and in stating possible actions or goals to be confidently pursued. By highlighting particular actions taken, such as attending international conferences, resolving particular problems or instructing officials to do certain things, he communicated his identity as a competent leader. He, however, rarely displayed the quality of a benevolent politician, who understands and shows empathy towards people's problems and needs. The two epistemic verbs which are found to be used most commonly to express benevolence are hěn 'see' and $k^{h} \hat{a} w c a j$ 'understand', which are used to display shared intersubjectivity with the people towards both positive and negative scenarios in Thailand. More specifically, the PM said he witnessed a good example of people who applied the King's philosophy in real life as well as understanding the people's 
Table 5. Overall frequency of stance markers and construction types enacting competency

\begin{tabular}{|c|c|c|c|}
\hline Markers & Frequency & Percentage & Stance Type and Construction \\
\hline dâ:j 'be able to' & 134 & $65.37 \%$ & $\begin{array}{l}\text { Modality } \\
\text { possibility/ability modal + verb-phrasal complement }\end{array}$ \\
\hline cà? 'will' & 44 & $21.46 \%$ & $\begin{array}{l}\text { Modality } \\
\text { volition/prediction modal + verb-phrasal complement }\end{array}$ \\
\hline tôy 'must' & 6 & $2.93 \%$ & $\begin{array}{l}\text { Modality } \\
\text { necessity/obligation modal + verb-phrasal complement }\end{array}$ \\
\hline$c^{h} \hat{u}: a / c^{h} \hat{u}$ :a.mân 'believe' & 6 & $2.93 \%$ & $\begin{array}{l}\text { Epistemic stance } \\
\text { likelihood verb }+ \text { sentential complement following wâ: }\end{array}$ \\
\hline kà:mlay 'to be going to' & 5 & $2.44 \%$ & $\begin{array}{l}\text { Modality } \\
\text { possibility/ability modal + verb-phrasal complement }\end{array}$ \\
\hline Pà:t.cà?/ k'oy.cà?/ 'may', 'can' & 3 & $1.46 \%$ & $\begin{array}{l}\text { Modality } \\
\text { possibility/ability modal + verb-phrasal complement }\end{array}$ \\
\hline mâj sa:mà:t cà? 'won't be able to' & 2 & $0.97 \%$ & $\begin{array}{l}\text { Modality } \\
\text { possibility/ability modal + verb-phrasal complement }\end{array}$ \\
\hline mâj Pà:t.cà?' 'may not be able to' & 2 & $0.97 \%$ & $\begin{array}{l}\text { Modality } \\
\text { possibility/ability modal + verb-phrasal complement }\end{array}$ \\
\hline sa:mà:t 'be able to' & 1 & $0.49 \%$ & $\begin{array}{l}\text { Modality } \\
\text { possibility/ability modal + verb-phrasal complement }\end{array}$ \\
\hline cà? tĥy 'will have to' & 1 & $0.49 \%$ & $\begin{array}{l}\text { Modality } \\
\text { possibility/ability modal + verb-phrasal complement }\end{array}$ \\
\hline Pà:t 'can', 'may' & 1 & $0.49 \%$ & $\begin{array}{l}\text { Modality } \\
\text { possibility/ability modal + verb-phrasal complement }\end{array}$ \\
\hline Total & 205 & $100 \%$ & Modality, Epistemic stance \\
\hline
\end{tabular}

hardship. As explained earlier, when negative scenarios like the citizen's economic hardship is emphasized, the PM used disclaimer ideological discourse strategy to dismiss his responsibility and instead asked for the entire nation's collaboration to solve conflicts.

Lastly, the interrelationship between the use of stance markers, discursive practice and social practice shows that the PM's attitudinal stance towards moral values and principles assigned to the nation's reform was produced, transmitted, and reinforced throughout his weekly addresses through the use of modal verbs and attitudinal verbs. The core moral concepts concerning collaborating with government agencies, upholding the monarchy, showing gratitude to parents, being patient and believing in the government's political actions were persistently delivered to manipulate people to capitulate to his power. The PM, however, rarely demonstrated the quality of benevolence through discursive devices and strategies. This lack of shared understanding with the people and responsibility denial when mâj rú:/ mâj sa:p 'don't know' is repeatedly used, therefore, causes him to appear like a manipulative political leader who requires people, but not his government, to change and adjust their values and attitudes, a basic foundation of national reform. While strongly persuading people to believe in what he has done, not many concrete and successful actions have been discursively construed to project his competency, one aspect of trust-building. Some information has been concealed and not been explicitly stated. This reflects Thai-style political discourse situated in an undemocratic country between March and December 2017 where political hegemony has been constructed through media manipulation and the mediation of linguistic devices.

\section{CONCLUSION}

The present study offers insights into how the Thai PM discursively shaped trust through analysis of his use of stance markers to project benevolence, integrity, and competency prior to the general election. The integrity aspect of trust was employed as the major discursive trust-building strategy, while competency and benevolence were rarely construed. This political hegemony and its relation to the PM's use of specific stance-taking acts projecting integrity reveal the sociocultural fact that Thais generally value goodness or the moral high ground and tend to link them with the quality of being trustworthy. Additionally, linguistic forms used to construe social responsibility denial and display little in-depth insights into social issues determine one form of political manipulation in the Thai sociopolitical context. However, it is impossible to definitely conclude that communicating integrity by strongly asserting the PM's stance towards moral values and beliefs and requiring people to comply with his set of beliefs is effective trust-building in the Thai political discourse since there are other various factors (e.g. timespan or global influences) influencing trust. More importantly, discourses appear to be interpreted differently by different groups of social actors with different backgrounds, beliefs and values. As Simpson, Harrell \& Willer (2013)'s study of trust indicates, the person's moral judgment is likely to affect how he or she perceives others 
as trustworthy, and future research in the area of trust in the political context and stance-taking acts may take into consideration the exploration of how different social groups in terms of age or social status make sense of trust through the use of different types of stance expressions projecting the three aspects of trust. This experimental study may be used to complement the qualitative or linguistic investigation in the field of discursive construction of trust in the Thai political context in the future.

\section{REFERENCES}

Biber, D., Conrad, S., and Cortes, V. (2004). If you look at...lexical bundles in university teaching and textbook. Applied Linguistics, 25(3), 371-405, https://doi. org/10.1093/applin/25.3.371

Biber, D., Johansson, S., Leech, G., Conrad, S., and Finegan, E. (1999). Longman Grammar of Spoken and Written English. Pearson Education Limited.

Bloommaert, J. and Bulcaen, C. (2000). Critical discourse analysis. Annual Review of Anthropology, 29, 447-466.

Carreon, J. R. and Svetanant, C. (2017). What lies underneath a political speech?: Critical discourse analysis of Thai PM's political speeches aired on the TV programme Returning Happiness to the People. Open Linguistics, 3, 638-655, https://doi.org/10.1515/opli-2017-0032.

Chilton, P. (2004). Analyzing political discourse: Theory and practice. London: Routledge.

Conrad, S. and Biber, D. (2005). The frequency and use of lexical bundles in conversation and academic prose. Lexicographica - International Annual for Lexicography, 20, 56-71.

De Saint-Georges, I. (2013). Context in the analysis of discourse and interaction. The Encyclopedia of Applied Linguistics, https://doi.org/10.1002/9781405198431. wbeal0194

Fairclough, N. (2010). Critical discourse analysis: The critical study of language. London: Longman.

Fairclough, N. (2003). Analysing discourse: Textual analysis for social research. New York: Routledge.

Fairclough, N. and Mauranen, A. (1997). Conversationalization of political discourse: A comparative view. In Jan

Bloommaert \& Chris Bulcaen (Eds.), Political Linguistics. Amsterdam: Benjamins. (pp. 89-119).

Fairclough, N. (1992). Discourse and text: Linguistic and intertextual analysis within discourse analysis. Discourse \& Society, 3(2), 193-217.
Fuoli, M. and Hart, C. (2018). Trust-building strategies in corporate discourse: An experimental study. Discourse and Society, 29(5), https://doi.org/10.1177/0957926518770264

Fuoli, M. (2017). Building a trustworthy corporate identity: A corpus-based analysis of stance in annual and corporate social responsibility reports. Applied Linguistics, $39(6), 846-855$.

Givón, T. (1990). Syntax: A functional typology introduction. Volume 2. Amsterdam/ Philadephia: John Benjamins.

Kegley, C.W. (2007). World politics: Trend and transformation. Belmont, CA: Thomson Wadsworth.

Kitikanan, P. (2012). Verb complementation in Thai. Journal of Humanities and Social Sciences Mahasarakham University, 31(3), 89-99.

Machin, D. and Mayr, A. (2012). How to do critical discourse analysis: A Multimodal Introduction. Los Angeles: Sage.

Prasithrathsint, A. (2009). Complementizers and verb classification in Thai. Journal of the Southeast Asian Linguistics Society, 2, 145-160.

Prevost, M., Brodeur, M. B., Onishi, K. H., Lepage, M., and Gold, I. (2015). Judging strangers' trustworthiness is associated with theory of mind skills. Frontier in Psychiatry, 6, https://doi.org/10.3389/fpsyt.2015.00052.

Rangkupan, S. (2005). A system of epistemic modality in Thai. MANUSYA: Journal of Humanities, 8(1), 53-67.

Salvi, R. (2017). The discursive construction of trust in European political communication. In R. Salvi \& J. Turnbull (Eds.), The discursive construal of trust in the $d y$ namics of knowledge diffusion (pp. 2-25). Newcastle upon Tyne: Cambridge Scholars Publishing.

Simpson, B., Harrell, A., and Willer, R. (2013). Hidden Paths from Morality to Cooperation: Moral Judgments Promote Trust and Trustworthiness. Social Forces, 91(4), 1529-1548.

van Dijk, T. A. (2013). Ideology and discourse. The $O x$ ford Handbook of Political Ideologies, https://doi. org/10.1093/oxfordhb/9780199585977.013.007

van Dijk, T. A. (2007). Ideology and discourse analysis. Journal of Political Ideologies, 11(2), 115-140, https:// doi.org/10.1080/13569310600687908

Wang, X. (2016). A struggle for trustworthiness: Local officials' discursive behaviour in press conferences handling Tianjin blasts in China. Discourse \& Communication, 10(4), https://doi.org/10.1177/1750481316638150

Wodak, R. (2009). The discourse of politics in action: Politics as usual. London: Palgrave Macmillan. 


\section{APPENDIX}

List of Glossing Abbreviations

$\begin{array}{ll}1 & \text { first person } \\ \text { ASP } & \text { aspect } \\ \text { BEN } & \text { benefactive } \\ \text { COMP } & \text { complementizer } \\ \text { COP } & \text { Copula } \\ \text { DIR } & \text { directional marker } \\ \text { EMP } & \text { emphasis } \\ \text { EPIS } & \text { epistemic modality } \\ \text { INCL } & \text { inclusion } \\ \text { IRR } & \text { irrealis mood } \\ \text { MAN } & \text { manipulative } \\ \text { MOD } & \text { modality } \\ \text { NEG } & \text { negation } \\ \text { NMZ } & \text { nominalizer } \\ \text { OBL } & \text { obligation } \\ \text { PERF } & \text { perfective } \\ \text { PL } & \text { plural } \\ \text { PN } & \text { pronoun } \\ \text { POSS } & \text { Possessive marker } \\ \text { PRSP } & \text { prospective aspect } \\ \text { PURP } & \text { Purpose } \\ \text { RECP } & \text { reciprocal } \\ \text { REL } & \text { relativizer } \\ \text { SG } & \text { singular } \\ \text { TAM } & \text { tense aspect or mood/modality } \\ \text { VOL } & \text { volition }\end{array}$

